\title{
Glutathione peroxidase activity and erythrocyte stability in calves differing in selenium and vitamin $E$ status
}

\author{
By R. C. SIDDONS* AND C. F. MILLS \\ The Rowett Research Institute, Bucksburn, Aberdeen, AB2 9SB
}

(Received 5 August 1980 - Accepted 15 May 1981)

1. Glutathione peroxidase astivity $(E C 1$ 1 11 1.9) and erythrocyte stability were measured in Friesian bull calves which were given for 36 weeks semi-purified diets either adequate or low in selenium or vitamin E or both.

2. Dietary Se or vitamin $E$ content had no effect on growth rate and haematological values. None of the calves exhibited clinical deficiency symptoms and serum aspartate amino transferase (EC 2.6.1.1) and creatine phosphokinase (EC 2.7.3.2) activities remained normal. Heart and skeletal muscles of all calves appeared macroscopically and microscopically normal at autopsy.

3. Glutathione peroxidase astivity in plasma, blood and other tissues, except the testis, was significantly lower in calves receiving low dietary Se but was independent of dietary vitamin $E$ content.

4. Plasma vitamin $E$ levels dexreased rapidly and to very low levels in calves given low vitamin $E$ diets irrespective of the Se content of the diet.

5. A low dietary vitamin E intake increased the susceptibility of erythrocytes to auto-and peroxidative haemolysis whereas a low Se intake in the presence of adequate vitamin E did not. However, erythrocytes from calves receiving low $\mathrm{Se}$ and low vitamin $\mathrm{E}$ were more susceptible to peroxidative haemolysis than erythrocytes from calves receiving low vitamin $\mathrm{E}$ and aclequate $\mathrm{Se}$. The effect of dietary vitamin $\mathrm{E}$ content on osmotic haemolysis induced by hypotonic saline was varialble.

6. The results suggest that measurement of blood glutathione peroxidase activity and the susceptibility of erythrocytes to auto- or peroxidative haemolysis could be used for the differential diagnosis of subclinical Se and vitamin $\mathrm{E}$ deficiency in rumine.nts.

The importance of selenium in animal nutrition, and its close metabolic interrelationship with vitamin $\mathbf{E}$ was first suggested by the observation that it could replace vitamin $\mathbf{E}$ in the prevention of dietary liver necrosis in the rat (Schwarz \& Folz, 1957). Subsequent studies have established it as an essential nutrient and have shown that requirements and deficiency symptoms vary and are dependent on other dietary components such as vitamin E, sulphur amino acids and unsaturated fatty acids (McCoy \& Weswig, 1969; Thompson \& Scott, 1969, 1970; Jenkins \& Hidiroglou, 1972).

Clinical disorders in ruminants in which a deficiency of Se has been implicated include nutritional muscular dystrophy in young calves and lambs (Jenkins \& Hidiroglou, 1972), paralytic myoglobinuria in cattle (Allen, Bradley et al. 1975; Johnston \& Murray, 1975), retained placenta in dairy cows (Trinder et al. 1973), unthriftiness in sheep and cattle, and peridontal disease and infertility in ewes (Andrews et al. 1968). However, in many of these naturally occurring conditions responses to vitamin $E$ treatment have also been obtained and the relative importance of Se or vitamin E deficiency in the aetiology of the disease is inadequately defined. For a more complete understanding of the relationships between Se and vitamin E deficiency in the cause of the disease, the development of relatively simple and reliable techniques for the differential diagnosis of Se and vitamin E deficiency is required.

Se is an integral part of glutathione peroxidase (GSHPx, EC 1.11.1.9), an enzyme involved in the conversion of lipid peroxides to hydroxyacids (Flohe et al. 1973; Rotruck et al. 1973). In a number of animal species including sheep (Oh, Pope et al. 1976) and cattle (Allen, Parr et al. 1975; Thomson et al. 1976), blood GSHPx activity has been found to

- Present address: The Grassland Research Institute, Hurley, Maidenhead, Berks. SL6 5LR. 
Table 1. Composition of the basal diets

(When diet $A$ was fed each calf was given intramusculary 125000 i.u. vitamin $A$ and 25000 i.u. vitamin $D_{3}$ weekly. Vitamins $A$ and $D_{3}$ were added to diets $B$ and $C$ at the rate of 25000 and 2500 i.u./kg respectively)

\begin{tabular}{llcc}
\hline \hline Diet $\mathrm{A}^{*}$ & & Diet B $(\mathrm{g} / \mathrm{kg})$ & Diet C $(\mathrm{g} / \mathrm{kg})$ \\
\hline Skim-milk powder $(180 \mathrm{~g})$ & Torula yeast & 400 & 50 \\
Cerelose $(40 \mathrm{~g})$ & Cerelose & 420 & 380 \\
Cream $\dagger(60 \mathrm{ml})$ & Cotton linters & 100 & 100 \\
& Starch & 00 & 350 \\
& Urea & 00 & 40 \\
& Fat & 50 & 20 \\
& Minerals & $30 \ddagger$ & 608 \\
\hline
\end{tabular}

- Reconstituted in 21 water and given twice daily.

$\dagger$ Contained $480 \mathrm{~g}$ fat $/ \mathrm{kg}$.

¥ The composition of the mineral wax was $(\mathrm{g} / \mathrm{kg}): \mathrm{CaCO}_{3}, 442 \cdot 60 ; \mathrm{NaCl}, 442 \cdot 60 ; \mathrm{MgSO}_{4} .7 \mathrm{H}_{2} \mathrm{O}, 109 \cdot 80$; $\mathrm{MnSO}_{4} \cdot 4 \mathrm{H}_{2} \mathrm{O}, 4 \cdot 31 ; \mathrm{CuSO}_{4} .5 \mathrm{H}_{2} \mathrm{O}, 0 \cdot 55 ; \mathrm{CoCl}_{2} \cdot 6 \mathrm{H}_{2} \mathrm{O}, 0 \cdot 14$.

$\S$ The composition of the mineral mix was $(\mathrm{g} / \mathrm{kg}): \mathrm{CaHPO}_{4} \cdot 2 \mathrm{H}_{2} \mathrm{O}, 396 \cdot 19 ; \mathrm{NaCl}, 222.63 ; \mathrm{MgSO}_{4} .7 \mathrm{H}_{2} 0,165 \cdot 91$; $\mathrm{KHCO}_{3}, 138 \cdot 19 ; \mathrm{Na}_{2} \mathrm{SO}_{4}, 69 \cdot 46 ; \mathrm{FeSO}_{4} .7 \mathrm{H}_{2} \mathrm{O}, 2.69 ; \mathrm{MnSO}_{4} .4 \mathrm{H}_{2} \mathrm{O}, 2 \cdot 88 ; \mathrm{ZnSO}_{4} .7 \mathrm{H}_{2} \mathrm{O}, 1.43 ; \mathrm{CuSO}_{4} .5 \mathrm{H}_{2} \mathrm{O}$, $0.52 ; \mathrm{CoCl}_{2} .6 \mathrm{H}_{2} \mathrm{O}, 0.07 ; \mathrm{KIO}_{3}, 0.03$.

be correlated with blood Se concentration, suggesting that it may provide a sensitive index of Se status. However, its value as a diagnostic tool is dependent on the activity being independent of all factors other than Se and also on defining the critical level of activity below which deficiency symptoms appear.

The purpose of the present study was to produce, by dietary deprivation, Se deficiency in young calves and, by monitoring the changes in blood GSHPx activity, to determine the relationship between blood GSHPx activity and the onset of myopathy as evidenced by increases in blood aspartate amino transferase (AAT, EC 2.6.1.1) and creatine phosphokinase (CPK, EC 2.7 .3 2) activities. The effect of the vitamin E status of the calves on this relationship was also examined. Unfortunately, although the Se and vitamin E content of the diets was below recommended dietary requirements, myopathy did not develop. The results did, however, confirm the relationship between Se intake, blood Se concentration and blood GSHPx activity and also showed that the activity of the enzyme was independent of vitamin E intake. In addition, erythrocyte stability studies suggested that the susceptibility of erythrocytes to haemolysis could serve as a useful index of vitamin E status.

\section{MATERIALS AND METHODS}

\section{Animals and diets}

Eight 4-week-old Friesian bull calves were used. They were housed individually, in wooden pens with sawdust bedding, in a temperature controlled calf rearing unit and given free access to tap water. At the beginning of the study, the calves were randomly allocated in pairs to four dietary groups. All calves were given basal diets formulated to contain low levels of Se and vitamin $\mathrm{E}$ but progressively changed in composition to meet requirements for suckling, pre-ruminating and ruminating phases of development (diets A, B \& C respectively, Table 1). Diet A was given for the first 3 weeks; calves were then weaned onto diet B, which was given until the end of the 9 th week. Thereafter, diet $C$ was given ad lib. The Se content of the three basal diets was $0.05,0.025$, and $0.024 \mathrm{mg} / \mathrm{kg}$ DM respectively. Only diet $\mathrm{C}$ was analysed for vitamin $\mathrm{E}$ content and contained $3.0 \mathrm{mg}$ total tocopherols $/ \mathrm{kg}$ DM. The basal diets were given either unsupplemented (low-Se, low-E group) or supplemented 
with Se (low-E group), with vitamin E (low-Se group) or both (control group). When such supplements were given they provided 0.20 (Diet A) or 0.25 (Diets B and C) $\mathrm{mg} \mathrm{Se} / \mathrm{kg}$ added as sodium selenite and 40 (Diet A) or 60 (Diets B and C) $\mathrm{mg} \alpha$ tocopherol $/ \mathrm{kg}$ (as Rovimix E50, Roche Products Lti, London). Daily food consumption and weekly weight gains were recorded. Blood sample; were taken from the jugular vein at regular intervals throughout the study, and at the end of the study the calves were slaughtered at the abattoir.

\section{Analytical methods}

GSHPx activity was measured by the enzyme-coupled method (Paglia \& Valentine, 1967) using an NADPH concerttration in the final incubation mixture of $0.15 \mathrm{~mm}$. A unit of enzyme activity is defined as that which results in the oxidation of $1 \mu \mathrm{mol} \mathrm{NADPH} / \mathrm{min}$. Haemolysates were kep1 at $4^{\circ}$ and assayed within $15 \mathrm{~min}$ of preparation because activity decreased on standing. GSHPx activity of other tissues was measured in the supernatant obtained after centrifuging a homogenate of the tissue at $18000 \mathrm{~g}$ for $10 \mathrm{~min}$ at $4^{\circ}$. The homogenate was prepared by homogenizing $0.5 \mathrm{~g}$ fresh tissue in $7 \mathrm{ml} 0.005 \mathrm{M}$-phosphate buffer $\mathrm{pH} \mathrm{7.0}$ containing $0.005 \mathrm{M}$-ethylene diamine tetraacetic acid for $5 \mathrm{~min}$ at $4^{\circ}$. The volume was adjusted to $10 \mathrm{ml}$ with phosphate buffer before centrifuging.

The susceptibility of erythrocytes to autohaemolysis was measured by incubating washed erythrocytes in saline-phosphate buffer containing $0.01 \mathrm{M}$-sodium azide at $37^{\circ}$ for $16 \mathrm{~h}$. The buffer was prepared by mixing equal volumes of phosphate buffer $\left(14.2 \mathrm{~g} \mathrm{Na}_{2} \mathrm{HPO}_{4}\right.$ adjusted to $\mathrm{pH} 7.4$ with $\mathrm{HCl}$ ) and saline-azide solution $(7.6 \mathrm{~g}$ sodium chloride and $1.3 \mathrm{~g}$ sodium azide/l). Four c.rops of heparinized blood were added to $5 \mathrm{ml}$ saline-phosphate buffer, mixed and centrifuged. The supernatant fraction was removed and the sedimented erythrocytes resuspended in $5 \mathrm{ml}$ buffer and incubated at $37^{\circ}$ for $16 \mathrm{~h} ; 0.5 \mathrm{ml}$ erythrocyte suspension was then removed and added to $9.5 \mathrm{ml}$ distilled water $(100 \%$ haemolysed sample). Both the suspension and the $100 \%$ haemolysed sample were centrifuged and the absorbance of the supesnatant fractions was measured at $415 \mathrm{~nm}$ on a Unicam SP 600 spectrophotometer. The percentage haemolysis was then calculated. The effects of glucose, ascorbic acid (neutralized with sodium carbonate) and hydrogen peroxide on haemolysis were studied using solutions of these compounds in phosphate-azide buffer and made isotonic with sodium chloride.

Erythrocyte osmotic stability was measured as follows: 15 drops of heparinized blood were added to $10 \mathrm{ml}$ bufiered isotonic saline (Dacie \& Lewis, 1968) mixed, centrifuged and the sedimented erythrosytes were resuspended in $12 \mathrm{ml}$ buffered isotonic saline; $1 \mathrm{ml}$ erythrocyte suspension was added to $4 \mathrm{ml}$ buffered isotonic saline which had been diluted with distilled water to give the required final saline concentration. The tubes were mixed and incubated at $4^{\circ}$ for $3 \mathrm{~h}$ before centrifuging. The absorbance of the supernatant was measured at $540 \mathrm{~nm}$ on a Unicam SP 600 spectrophotometer and the percentage haemolysis was calculated by refererice to a $100 \%$ haemolysed sample, i.e. $1 \mathrm{ml}$ erythrocyte suspension plus $4 \mathrm{ml}$ distilled water

Plasma vitamin E concentration was measured by the method of Hashim \& Schutteringer (1966) and Se in feed and blood was measured fluorimetrically (Oh et al. 1974). Serum CPK activity was assayed according to the Sigma technical bulletin No. 40-UV and Serum AAT activity by an autoanalyser technique (Dickie et al. 1970).

\section{Statistical analysis}

The basic analysis was for a $2 \times 2$ factorial with two animals per treatment. Where time responses were examined these have been treated as a split plot treatment as discussed in Steel \& Torrie (1960). Erythrocyte haemolysis data were subjected to analysis of variance, using angular transformation, to isolate diet and substrate differences, and Newman Keuls 
test (Miller, 1966) was used to identify significant differences using the standard error of the means based on minimum replication.

\section{RESULTS}

\section{General observations}

Dietary Se or vitamin E content had no significant effect on growth rate and haematological values. The mean body weight of the calves at the beginning of the study was $41 \mathrm{~kg}(\mathrm{sE} \pm 1 \cdot 1)$ and at the end it was $261 \pm 5 \mathrm{~kg}$. Erythrocyte count decreased from an initial mean value of $9 \cdot 11 \pm 0.31 \times 10^{12} / 1$ to $7 \cdot 95 \pm 0.25 \times 10^{12} / 1$ at 12 weeks and thereafter remained relatively constant. The blood haemoglobin concentration followed a similar pattern, decreasing from $139 \pm 5.0 \mathrm{~g} / 1$ to $108 \pm 2.5 \mathrm{~g} / 1$ at 12 weeks and then remained relatively constant.

None of the calves developed clinical deficiency symptoms and no histological evidence of skeletal or cardiac myopathy was found at autopsy. The livers of all calves were pale and friable and light microscopy after staining with Oil Red 0 revealed considerable fatty infiltration. The extent of the infiltration was similar in all calves and was not related to the $\mathrm{Se}$ or vitamin $\mathrm{E}$ content of the diet.

There was no significant effect of diet on serum AAT and CPK activities. Serum AAT activity ranged between 19-47 U/1 (mean $29 \mathrm{U} / 1$ ) and serum CPK activity ranged between 12-37 Sigma units $/ \mathrm{ml}$ (mean 22 units $/ \mathrm{ml}$ ). During the 18 th and 19 th week of the experiment the calves were exercised daily for $1 \mathrm{~h}$. One of the calves in the low-Se, low-E group exhibited breathlessness but otherwise no symptoms were observed. On the final day of the two-week exercise period, serum CPK activity was measured before and after exercise. A small increase in CPK activity occurred in most of the calves and although it tended to be more marked in the two calves given the low-Se, low-vitamin E diet (to 161 and 199 units $/ \mathrm{ml}$ ), an increase of a similar magnitude occurred in one of the calves in the control group (to 167 units $/ \mathrm{ml}$ ). In all calves the activity had decreased by the following day and remained low thereafter.

\section{Glutathione peroxidase activity}

Kinetic studies showed that the $\mathrm{pH}$ activity curve for calf blood GSHPx was similar to that for human blood GSHPx (Paglia \& Valentine, 1967) with activity increasing over the $\mathrm{pH}$ range studied (6.0-8.0) in a sigmoidal manner. The $K_{m}$ values for glutathione $\left(4 \cdot 85 \times 10^{-3} \mathrm{M}\right)$ and hydrogen peroxide $\left(0.91 \times 10^{-5} \mathrm{M}\right)$ were also similar to the $K_{m}$ values obtained for human blood GSHPx activity (Paglia \& Valentine, 1967). The major proportion of whole blood GSHPx activity was located in the erythrocytes $(>0.90)$ and only a small proportion was present in the plasma (approximately 0-01).

The levels of GSHPx activity in blood and plasma were measured at regular intervals throughout the study and statistical analysis of the results showed a significant $(P<0.001)$ effect of both time and dietary Se content but not dietary vitamin $E$ content upon activity. The GSHPx activity of other tissues was also independent of dietary vitamin E content, and in reporting the results the vitamin $\mathbf{E}$ status of calves and diets has been ignored and data are grouped according to the Se content of the diet, i.e. low-Se and Se-supplemented. The changes in plasma and blood GSHPx activity of the two groups are shown in Fig. 1. Plasma activity decreased initially in both groups but the decrease was more rapid and to a greater extent in the low-Se group. Minimum levels of approximately $0.03 \mathrm{units} / \mathrm{ml}$ in the low-Se group and $0.10 \mathrm{units} / \mathrm{ml}$ in the Se-supplemented group were attained at 8 and 16 weeks respectively. Whole blood GSHPx activity in the low-Se group remained unchanged during the first 4 weeks and then decreased to reach a minimum level of approximately 15 units/g haemoglobin at 16 weeks. In the Se-supplemented group, activity increased continuously during the first 22 weeks to a maximum level of approximately 300 units $/ \mathrm{g}$ 


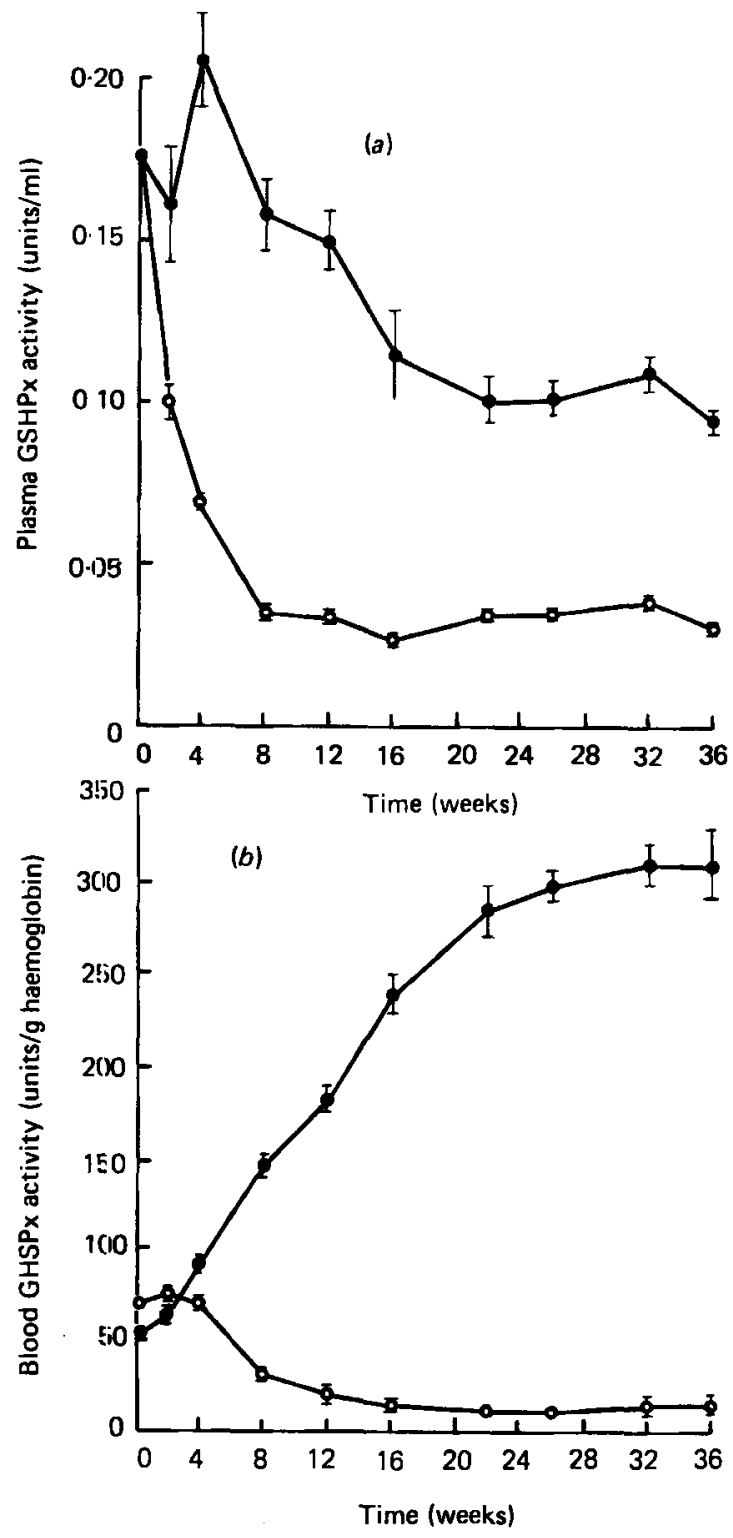

Fig. 1. Changes in plasrna and blood glutathione peroxidase activity of calves given diets containing different amounts of selenium. Mean values for four calves with standard errors indicated by vertical lines. ( $a$ ) plasma activity, (b) blood activity. The calves were given low-selenium, low-vitamin $\mathrm{E}$ basal diets, either unsuppleme:1ted or supplemented with Se, vitamin E or both. (For details, see p. 346 and Table 1). The vitamin $E$ content of the diet had no effect on glutathione peroxidase activity and the calves have been groupel according to the Se content of the diet, i.e. low-Se $(O)$ or Se-supplemented (O). 
Table 2. Glutathione peroxidase activity (units/g tissue) in tissues from calves given diets containing different amounts of selenium $\dagger$

(Results are means for 4 calves in each group)

\begin{tabular}{|c|c|c|c|c|}
\hline & Low-Se & Se-supplemented & SEM & $\begin{array}{l}\text { Significance } \\
\text { of difference }\end{array}$ \\
\hline Spleen & $5 \cdot 47$ & $21 \cdot 61$ & 1.74 & $* *$ \\
\hline Kidney & $8 \cdot 43$ & $21 \cdot 55$ & 1.09 & $* *$ \\
\hline Pancreas & $2 \cdot 13$ & 18.26 & 0.82 & $* * *$ \\
\hline Heart & 2.53 & 16.92 & $1 \cdot 11$ & $* * *$ \\
\hline Liver & 1.06 & $15 \cdot 39$ & 0.50 & $* * *$ \\
\hline Lung & 1.92 & 14.62 & $1 \cdot 24$ & $* *$ \\
\hline Testis & $10 \cdot 16$ & 11.02 & 0.92 & NS \\
\hline Diaphragm & 0.26 & $5 \cdot 42$ & 0.33 & $* * *$ \\
\hline \multicolumn{5}{|l|}{ Muscles } \\
\hline Infraspinatus & 0.68 & $5 \cdot 70$ & 1.00 & $*$ \\
\hline Supraspinatus & 0.25 & $5 \cdot 32$ & $1 \cdot 17$ & * \\
\hline Long head of triceps & 0.23 & $2 \cdot 59$ & 0.15 & $* * *$ \\
\hline Lateral head of triceps & $0 \cdot 16$ & $2 \cdot 76$ & 0.50 & $*$ \\
\hline
\end{tabular}

NS, not significant $(P>0.05)$.

$* P<0.05, * * P<0.01, * * * P<0.001$.

$\dagger$ The calves had been given for 36 weeks low-Se, low-vitamin E basal diets either unsupplemented or supplemented with Se, vitamin $\mathrm{E}$ or both. (For details, see p. 346 and Table 1). The vitamin E content of the diet had no effect on tissue glutathione peroxidase activity and the calves have been grouped according to the Se content of the diet.

haemoglobin. Thus, at the end of the study there was a twenty fold difference in the blood activity of the two groups but only a threefold difference in plasma activity.

Blood samples taken during the 32nd week were analysed for Se, and as with GSHPx activity, blood Se was not influenced by dietary vitamin $\mathrm{E}$ content. The levels in low-Se group (mean $0.022 \pm 0.0012 \mathrm{mg} / \mathrm{l})$ were significantly $(P<0.001)$ lower than in the Sesupplemented group (mean 0.158 $\pm 0.0044 \mathrm{mg} / \mathrm{l}$ ).

The GSHPx activity of various tissues taken at the end of the study is shown in Table 2. Testicular activity was similar in the low-Se and Se-supplemented calves, whereas for all other tissues the activity was significantly lower in the low-Se calves.

\section{Plasma vitamin E concentration}

The Se content of the diet had no significant effect on plasma vitamin $\mathrm{E}$ concentration, whereas the vitamin E content did. Therefore, in Fig. 2 the calves have been grouped according to the vitamin $E$ content of the diet. The plasma vitamin $E$ concentration in calves in the low-vitamin E group decreased rapidly and to very low levels, and from the 16th week onwards the concentration was too low $(<0.1 \mathrm{mg} / \mathrm{l})$ to measure with the assay procedure used. Vitamin $\mathrm{E}$ supplementation of the diet resulted in higher plasma vitamin E concentrations although there was considerable variation both between and within animals.

\section{Erythrocyte stability}

In the 30th week of the experiment it was noted that blood samples taken from calves not receiving the vitamin $E$ supplement haemolysed when left at room temperature. Therefore, during the last 6 weeks of the study, erythrocyte stability studies were undertaken.

The effect of dietary vitamin $E$ on the susceptibility of erythrocytes to autohaemolysis 


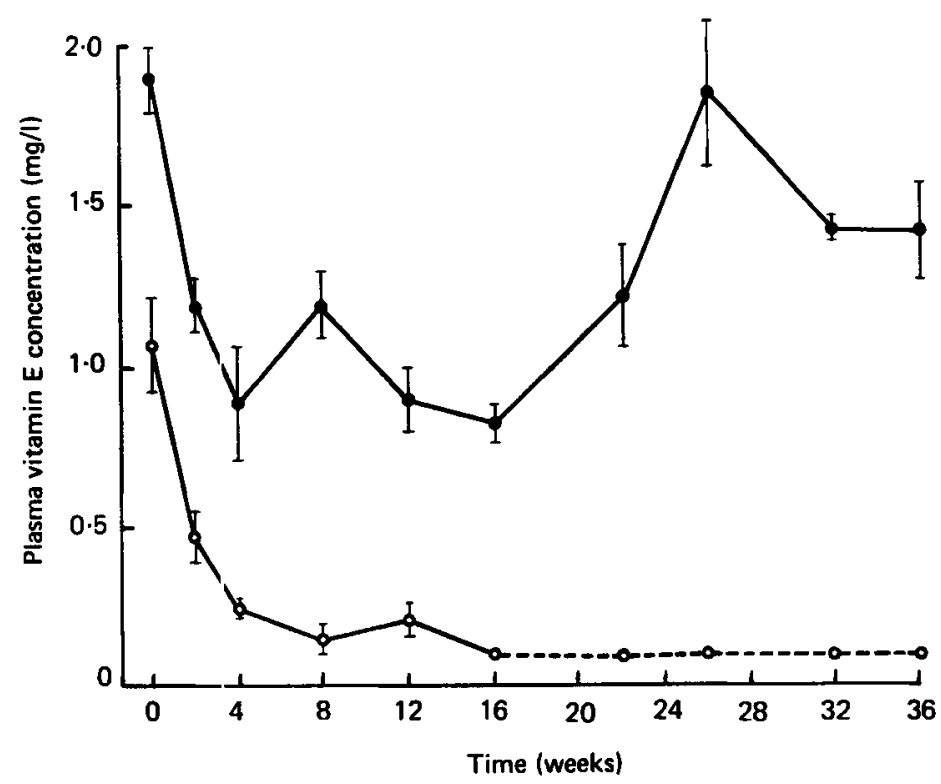

Fig. 2. Changes in plasma vitamin E concentration of calves given diets containing different amounts of vitamin $\mathbf{E}$. Mean values for four calves with standard errors indicated by vertical lines. The calves were given low-selenium, low-vitamin $\mathrm{E}$ basal diets either unsupplemented or supplemented with $\mathrm{Se}$, vitamin E or both. (For details, see p. 346 and Table 1). The Se content of the diet had no effect on plasma vitamin $\mathbf{E}$ concentration and the calves have been grouped according to the vitamin $\mathrm{E}$ content of the diet, i.e. low-vitamin $\mathrm{E}(\mathrm{O})$ or vitamin-E-supplemented $(O)$. From the 16th week onwards the concentration in the low-vitamin E group was too low $(<0.1 \mathrm{mg} / \mathrm{l})$ to measure with the assay procedure used.

Table 3. Susceptibility of erythrocytes from calves given diets containing different amounts of vitamin $E \ddagger$ to autohaemolysis and peroxidative haemolysis

(No. of blood samples assayed per calf given in parentheses; four calves in each group. Results are expressed as proportion of erythrocytes haemolysed and are mean values with their standard errors)

\begin{tabular}{|c|c|c|c|c|c|}
\hline & \multicolumn{2}{|c|}{ Low vitamin $\mathbf{E}$} & \multicolumn{2}{|c|}{$\begin{array}{c}\text { Vitamin E } \\
\text { supplemented }\end{array}$} & \multirow{2}{*}{$\begin{array}{l}\text { Significance } \\
\text { of difference }\end{array}$} \\
\hline & Mean & SE & Mean & SE & \\
\hline Autohaemolysis & $0 \cdot 187$ & $0.0189(8)$ & 0.006 & $0.0007(4)$ & * \\
\hline \multicolumn{6}{|l|}{ Peroxjdative haemolysis } \\
\hline ascorbate-induced & 0.427 & $0.0561(6)$ & 0.008 & $0.0008(4)$ & * \\
\hline hydrogen peroxide-induced & 0.538 & $0.0433(6)$ & 0.006 & $0.0005(4)$ & $* *$ \\
\hline
\end{tabular}

- $P<0.05, \quad * * P<0.01$.

+ Determined by analysis of transformed data.

¥ The calves had been given for at least 30 weeks low-Se, low-vitamin E basal diets either unsupplemented or supplemented with vitamin E. 'Within each group two of the calves were also given Se (for details, see p. 346 and Table 1).

and to peroxidative haemolysis is shown in Table 3. Erythrocytes from calves in the control group and the low-Se group, i.e. those calves receiving vitamin E, were resistant to both auto- and peroxidative haemolysis (proportion haemolysed $<0.01$ ) whereas significantly higher levels of auto- $(P<0.05)$ and ascorbate- $(P<0.05)$ or hydrogen peroxide- $(P<0.01)$ induced peroxidative hatemolysis occurred with erythrocytes from calves not receiving 
Table 4. Erythrocyte haemolysis in calves given diets deficient in vitamin $E$ with or without supplementary selenium*

(No. of blood samples assayed per calf given in parentheses; two calves in each dietary group. Results expressed as proportion of erythrocytes haemolysed)

\begin{tabular}{|c|c|c|c|c|c|c|c|}
\hline Substrate $\ldots$ & None & $\begin{array}{c}\text { Glucose } \\
(11 \cdot 1 \mathrm{~mm})\end{array}$ & $\begin{array}{l}\text { Ascorbate } \\
(0.11 \mathrm{mM})\end{array}$ & $\begin{array}{l}\text { Ascorbate }+ \\
\text { glucose }\end{array}$ & $\begin{array}{c}\mathrm{H}_{2} \mathrm{O}_{2} \\
(0.02 \mathrm{mM})\end{array}$ & $\begin{array}{c}\mathrm{H}_{2} \mathrm{O}_{2}+ \\
\text { glucose }\end{array}$ & SEM† \\
\hline Dietary group: & (8) & (8) & $(5)$ & (5) & (6) & (6) & \\
\hline- vitamin $E+S e$ & $0.28^{\mathrm{de}}$ & $0.01^{\mathrm{g}}$ & $0.23^{\mathrm{e}}$ & $0 \cdot 17^{\text {ef }}$ & $0 \cdot 36^{d}$ & $0 \cdot 11^{f}$ & $\begin{array}{c}0.031 \\
(1.964)\end{array}$ \\
\hline -vitamin E-Se & $0 \cdot 10^{f}$ & $0.03 \mathrm{~g}$ & $0.62^{\mathrm{ab}}$ & $0-53^{\mathrm{bc}}$ & $0.72^{a}$ & $0.47^{c}$ & \\
\hline
\end{tabular}

a,b,c,d,e,f,g Values with different superscripts are significantly different $(P<0.05)$.

* Calves were given basal diets low in vitamin $\mathrm{E}$ and containing either 0.025 or $0.25 \mathrm{mg} \mathrm{Se} / \mathrm{kg}$ for at least 30 weeks (for details, see p. 346 and Table 1). Similar studies were also carried out with erythrocytes from calves receiving vitamin E-supplemented diets with or without added $\mathrm{Se}$ and the proportion of erythrocytes susceptible to either auto or peroxidative haemolysis was less than $0 \cdot 01$.

$\dagger$ SEM based on transformed data given in parentheses.

vitamin E. Furthermore, statistical analysis of the results for the calves not receiving vitamin $E$ showed a significant effect of dietary Se on erythrocyte haemolysis (Table 4). Autohaemolysis was higher when the diet was low in vitamin $\mathbf{E}$ and supplemented with Se than when it was low in both vitamin $\mathrm{E}$ and $\mathrm{Se}$. In both groups autohaemolysis was reduced by inclusion of glucose in the incubation medium. Ascorbic acid did not stimulate haemolysis of erythrocytes from calves in the low-E group but caused a sixfold increase in haemolysis of erythrocytes from calves in the low-E, low-Se group. Similarly, hydrogen peroxide had little effect on haemolysis in the low-E group but markedly increased $(\times 7 \cdot 2)$ haemolysis in the low-E, low-Se group. Glucose was more effective in reducing hydrogen peroxide-induced haemolysis than in reducing ascorbate-induced haemolysis but in all cases peroxidative haemolysis occurring in the presence of glucose was quite high.

Erythrocyte osmotic stability studies were also undertaken but the results were less clear-cut than the haemolysis results. Erythrocytes from both calves in the low-Se, low-E group exhibited marked fragility when exposed to hypotonic saline. This was also the case, although to a lesser extent, for one of the calves in the low-E group, whereas erythrocytes from the other calf in the low-E group and from both calves in the low-Se group exhibited a similar osmotic stability to erythrocytes from the two calves in the control group. For example, at a saline concentration of $6.25 \mathrm{~g} / 1$, the proportion of erythrocytes which lysed was 0.73 and 0.76 for the low-E, low-Se group, 0.45 and 0.18 for the low-E group, 0.19 and 0.32 for the low-Se group and $\mathbf{0 . 2 2}$ and 0.28 for the control group.

\section{DISCUSSION}

Se requirements of most animal species, including ruminants, are generally considered to be approximately $0.05 \mathrm{mg} / \mathrm{kg}$ (Agricultural Research Council, 1979). However, Se and vitamin $\mathrm{E}$ requirements are known to be interdependent and when dietary Se is below $0.1 \mathrm{mg} / \mathrm{kg}$ the vitamin $\mathrm{E}$ content of the diet may become an important factor in the prevention of NMD (Jenkins \& Hidiroglou, 1972). Both the Se and vitamin E content of the basal diets used in the present study were considerably lower than the above and other suggestions of requirement (Sorensen, 1973; Rumsey, 1975; NAS-NRC, 1976), but there was no effect on growth rate, which averaged $0.87 \mathrm{~kg}$ live-weight gain/d over the 36 -week period, and none of the calves exhibited clinical, subclinical or histological symptoms of 
myopathy. This suggests that factors other than a low Se and vitamin $E$ intake may be involved in the aetiology of NMD in calves. The disease has been experimentally induced in calves by feeding diets low in vitamin $\mathrm{E}$ and high in polyunsaturated fatty acids (PUFA). However, when the PUFA were omitted from the diet, clinical symptoms did not develop (Blaxter, 1962). Unaccustomed exercise may be a predisposing factor in the development of clinical myopathy since naturally occurring NMD in young calves and paralytic myoglobinuria in older cattle is most commonly seen when the animals are turned out to pasture after winter housing (Sharman, 1954; Holmes et al. 1972; Allen, Bradley et al. 1975; Johnston \& Murray, 1975). In the present study, limited exercise during weeks 18 and 19 did not induce clinical symptoms and only a transient increase in serum CPK activity occurred. Anderson et al. (1977) noted transient increases in CPK activity of calves when turned out to pasture, irrespective of their Se or vitamin E status. In some calves, mainly those receiving diets low in Se and vitamin $\mathrm{E}$, there was a secondary rise in activity which occurred between 5 and $9 \mathrm{~d}$ after turn-out.

Although the diets used in the present study did not induce clinical or subclinical myopathy, the Se and vitamin E status of the calves, as assessed by other criteria, varied according to dietary inlake. Dietary Se content had a significant effect on blood GSHPx activity and blood Se concentration, whereas the vitamin E content did not. The absence of an effect of dietary vitamin E content on blood GSHPx activity is obviously an important prerequisite for its use z.s an index of the Se status of cattle, as suggested by Allen, Parr $\boldsymbol{e t}$ al. (1975). Blood GSHPx activity has advantages over blood Se concentration as an index of Se status in that it is easier to assay, is not likely to be subject to error through contamination and is more likely to reflect the biologically available Se content of tissues. Se can be present in tissues in a non-functional form due to the formation of complexes with heavy metals (Hill, 1974; Jensen, 1975).

The resistance of testicular GSHPx to changes in Se intake confirms for cattle findings with lambs (Oh, Sunde et al. 1976) and rats (Chow \& Tappel, 1974). It suggests that the testis is able to accumulate Se preferentially (Brown \& Burk, 1973), or that the GSHPx activity of the testis is not Se dependent (Lawrence \& Burk, 1978). The GSHPx activity of other tissues was dependent on Se intake and was significantly lower in calves given low Se diets. The very low activity found in skeletal muscle is consistent with the suggestion of Whanger $e$ t al. (1977) that the apparent species difference in the pattern of distribution of GSHPx activity betwreen tissues may be a contributory factor to the species difference in tissue response to Se deficiency.

Blaxter \& Sharman (1953) found plasma vitamin E concentrations of $0.4 \mathrm{mg} / 1$ or less in calves with vitamin E-responsive nutritional muscular dystrophy compared with $1.5 \mathrm{mg} / \mathrm{l}$ in normal calves. In the present study the plasma vitamin $\mathrm{E}$ concentration in the calves receiving the vitamin E-supplemented diet ranged between $0.53-2.27 \mathrm{mg} / 1$ and in calves given no vitamin $E$ supplement it decreased to below $0.1 \mathrm{mg} / \mathrm{l}$. However, the fall in the plasma concentration on the low diets was very rapid, indicating high sensitivity to changes in dietary intake, a factor which would limit its usefulness as a reliable index of the vitamin $E$ status of the animal.

In monogastric animals the susceptibility of erythrocytes to auto- or peroxidative haemolysis has been found to be a sensitive index of vitamin E status (Draper \& Csallany, 1969; Rose \& Gyorgy, 1950). It has also been shown that in addition to a low vitamin E status, the concentration of PUFA and in particular arachidonic acid, in the erythrocyte membrane is an important factor influencing the susceptibility of erythrocytes to haemolysis (Bieri \& Poukka, 1970; Brin et al. 1974; Horn et al., 1974). Tappel (1974) proposed that the protective effect of vitamin $E$ on membrane structure is mediated through its ability to limit the proliferation of free radical chain reactions promoting PUFA peroxidation in the phospholipid core of membranes. The phospholipid hydroperoxides produced in such 
a chain reaction undergo homolytic decomposition with consequent free radical damage to nearby molecules. Se in the form of GSHPx exerts a secondary defence mechanism by converting the lipid hydroperoxides to hydroxy acids and so preventing the homolytic decomposition.

Dietary PUFA content has a marked effect on tissue PUFA content in monogastric but less effect in ruminant animals due to biohydrogenation in the rumen (Shorland et al. 1955; Tove, 1960). Therefore, it might be expected that the PUFA content of ruminant erythrocyte membranes would be less readily increased by dietary changes and be less susceptible to peroxidation and haemolysis. Poukka \& Oksanen (1972) found that erythrocytes from calves fed on a dystrophogenic low vitamin $\mathbf{E}$ diet containing maize oil did not exhibit increased haemolysis. In contrast, maize oil, but not cod liver oil, induced erythrocyte haemolysis in lambs given low vitamin E diets, whereas cod liver oil, but not maize oil, induced NMD (Boyd, 1968). The possibility thus exists that events provoking erythrocyte fragility in animals offered diets low in vitamin $\mathrm{E}$ may not be closely related to those provoking myopathy.

Results obtained in the present study showed that vitamin $\mathrm{E}$, but not Se, was necessary for the stabilization of calf erythrocytes and increased auto- and peroxidative haemolysis occurred in all calves not given supplemental vitamin $\mathrm{E}$, whereas a low-Se intake in the presence of added vitamin $\mathrm{E}$ did not result in increased haemolysis. Osmotic stability studies were less conclusive in demonstrating a requirement for vitamin $\mathrm{E}$ for the stabilization of calf erythrocytes because, although increased osmotic lysis occurred with erythrocytes from both calves in the low-Se, low-E group and also with erythrocytes from one of the calves in the low-E group, erythrocytes from the other calf in the low-E group exhibited similar osmotic stability as erythrocytes from calves given vitamin E. Osmotic stability would therefore not appear to be a reliable method of assessing vitamin E deficiency in cattle. Brin et al. (1974) found that erythrocytes from vitamin E-deficient rats were less susceptible to osmotic lysis than erythrocytes from rats given vitamin $\mathrm{E}$, but were more susceptible to peroxidative haemolysis.

The reasons for the higher erythrocyte autohaemolysis observed when calves offered a low vitamin $\mathrm{E}$ diet were given Se are not yet clear and merit further investigation. However, it is possible that the provision of Se in excess of requirements may itself induce an oxidant stress. Hafeman et al. (1974) have proposed that an oxidant stress induced by excess dietary selenite may explain the continued increase in GSHPx activity in response to increases in dietary selenite at levels above requirements.

The stimulatory effect of ascorbic acid and $\mathrm{H}_{2} \mathrm{O}_{2}$ on haemolysis of erythrocytes obtained from calves low in vitamin $E$ and $S e$ but the absence of this effect when animals were given Se presumably reflects the ability of the higher GSHPx activity of the erythrocytes of the calves in the latter group to protect against the harmful effects of such added oxidants. Glucose also conferred some degree of protection against haemolysis most probably by generating reduced glutathione (Rotruck et al. 1972).

The findings suggest that the susceptibility of erythrocytes to autohaemolysis may provide a useful index of the vitamin $\mathbf{E}$ status of ruminants and that differential haemolytic responses to the in vitro treatment of erythrocytes with peroxide or ascorbate could provide the basis of a preliminary screening procedure for the detection of a low vitamin $\mathrm{E}$, low Se status. Although the studies of Kursa \& Kroupova (1976) indicate the existence of a high susceptibility to erythrocyte haemolysis in calves with naturally occurring clinical or subclinical NMD, the existence of such a relationship in instances of NMD arising from a clearly identified and naturally occurring deficiency of Se remains to be investigated.

The authors thank Mrs J. J. B. Willis for her technical assistance, Messrs W. Lawson for doing the haematological analysis, L. Leigh for histological examination of the tissues and 
Dr S. H. Oh for Se analyses. Messrs Roche Products Ltd, London, kindly donated the vitamin $A, D$ and $E$ sources used in this study.

\section{REFERENCES}

Agricultural Research Council (1979). Nutrient Requirements of Farm Livestock, III Ruminants (2nd edn). London: Agricultural Research Council.

Allen, W. M., Bradley, R., Berrett, S., Parr, W. H., Swannack, K., Barton, C. R. Q. \& MacPhee, A. (1975). Br. vet. J. 131, 292.

Allen, W. M., Parr, W. H., Anderson, P. H., Berrett, S., Bradley, R. \& Patterson, D. S. (1975). Vet. Rec. 96, 360.

Anderson, P. H., Bradley, R., Berrett, S. \& Patterson, D. S. P. (1977). Br. vet. J. 133, 160.

Andrews, E. D., Hartley, IV. J. \& Grant, A. B. (1968). N.Z. Vet. J. $16,3$.

Bieri, J. G. \& Poukka, R. K. H. (1970). J. Nutr. 100, 557.

Blaxter, K. L. (1962). Proc. Nutr. Soc. 21, 211.

Blaxter, K. L. \& Sharman, G. A. M. (1953). Nature, Lond. 172, 1006.

Boyd, J. W. (1968). Br. J. Nutr. 22, 411.

Brin, M., Horn, L. R. \& Barker, M. O. (1974). Am. J. clin. Nutr. 27, 945.

Brown, D. G. \& Burk, R. F. (1973). J. Nutr. 103, 102.

Chow, C. K. \& Tappel, A. L. (1974). J. Nutr. 104, 444.

Dacie, J. V. \& Lewis, S. M. (1968). Practical Haematology, (4th edn). London: Churchill.

Dickie, A. C., Gibson, P. F. \& Albert-Recht, F. (1970). Ann. clin. Biochem. 7, 158.

Draper, H. H. \& Csallany, A. S. J. (1969). J. Nutr. 98, 390.

Flohe, L., Gunzler, W. A. \& Schook, H. H. (1973). F.E.B.S. Lett. 32, 132.

Hafeman, D. G., Sunde, R. A. \& Hoekstra, W. G. (1974). J. Nutr. 104, 580.

Hashim, S. A. \& Schutteringer, G. R. (1966). Am. J. clin. Nutr. 19, 137.

Hill, C. H. (1974). J. Nutr. 104, 593.

Hoffman, I., Jenkins, K. J., Meranger, J. C. \& Pidgen, W. J. (1973). Can. J. Anim. Sci. 53, 61.

Holmes, J. H. G., Ashmort, C. R., Robinson, D. W., Finn, J. P. \& O'Dell, J. (1972). Vet. Rec. $90,625$.

Horn, L. R., Barker, M. O., Reed, G. \& Brin, M. (1974). J. Nutr. 104, 192.

Jenkins, K. J. \& Hidirogloı, M. (1972). Can. J. Anim. Sci. 52, 591.

Jensen, L. S. (1975). J. Nur. 10S, 769.

Johnston, W. S. \& Murray, I. S. (1975). Vet. Rec. 97, 176.

Kursa, J. \& Kroupova, V. (1976). Res. vet. Sci. $20,97$.

Lawrence, R. A. \& Burk, R. F. (1978). J. Nutr. 108, 211.

Lineweaver, H. \& Burk, D. (1934). J. Am. chem. Soc. 56, 658.

McCoy, K. E. \& Weswig, P. H. (1969). J. Nutr. 98, 383.

Miller, R. G. (1966). Simultaneous Statistical Inference. New York: McGraw-Hill Book Company Inc.

Muth, O. H., Oldfield, J. E., Remmert, L. F. \& Schubert, J. R. (1958). Science, N.Y. $128,1090$.

NAS-NRC (1976). Nat. Acad. Sci. Nat. Res. Counc. Nutrient requirements of beef cattle. Washington DC: NAS, NRC.

Oh, S. H., Ganther, H. E. \& Hoekstra, W. G. (1974). Biochemistry 13, 825.

Oh, S. H., Pope, A. L. \& Hoekstra, W. G. (1976). J. Anim. Sci. 42, 984.

Oh, S. H., Sunde, R. A., Pope, A. L. \& Hoekstra, W. G. (1976). J. Anim. Sci. 42, 977.

Paglia, D. E. \& Valentine, W. N. (1967). J. Lab. clin. Med. 70, 158.

Pederson, N. D., Whanger. P. D. \& Weswig, P. H. (1975). Nutr. Rep. Int. 11, 429.

Poukka, R. \& Oksanen, A. (1972). Br. J. Nutr. 27, 327.

Rose, C. S. \& Gyorgy, P. (1950). Proc. Soc. exp. Biol. Med. 74, 411.

Rotruck, J. T., Pope, A. L., Ganther, H. E. \& Hoekstra, W. G. (1972). J. Nutr. $102,689$.

Rotruck, J. T., Pope, A. L.: Ganther, H. E., Swanson, A. B., Hafeman, D. G. \& Hoekstra, W. G. (1973). Science, N.Y. 179, 588.

Rumsey, T. S. (1975). Feec'stuffs 17, 30.

Schwarz, K. \& Folz, C. M. (1957). J. Am. chem. Soc. 79, 3293.

Sharman, G. A. M. (1954), Vet. Rec. 66, 275.

Shorland, F. B. Weenink, R. O. \& Johns, A. T. (1955). Nature, Lond. 175, 1129.

Sorensen, P. H. (1973). Ac:a agric. Scand. suppl. 19, 177.

Steel, R. G. D. \& Torrie, J. H. (1960). Principles and Procedures of Statistics. New York: McGraw-Hill Book Company Inc.

Tappel, A. L. (1974). Am. J. clin. Nutr. $27,960$.

Thompson, J. N. \& Scott, M. L. (1969). J. Nutr. 97, 335.

Thompson, J. N. \& Scott, M. L. (1970). J. Nutr. 100, 797.

Thompson, R. H., McMurray, C. H. \& Blanchflower, W. J. (1976). Res. vet. Sci. $20,229$.

Tove, S. B. (1960). J. Dairv Sci. 43, 1354.

Trinder, N., Hall, R. J. \& Penton, C. P. (1973). Vet. Rec. 93, 641.

Whanger, P. D., Weswig, l'. H., Schmitz, J. A. \& Oldfield, J. E. (1977). J. Nutr. $107,1298$. 